\title{
Effects of micronized sodium chloride on the sensory profile and consumer acceptance of turkey ham with reduced sodium content
}

Maria Teresa Esteves Lopes GALVÃO ${ }^{1 *}$, Debora Braga MOURA², Andrea Carla Silva BARRETTO ${ }^{3}$, Marise Aparecida Rodrigues POLLONIO ${ }^{1}$

\begin{abstract}
The impact of sodium chloride reduction and its substitution for micronized salt on consumer acceptance of turkey ham was investigated. Five formulations - F1 (control - 2.0\% NaCl), F2 (1.7\% NaCl), F3 (1.4\% NaCl), F4 (1.7\% micronized NaCl), and F5 $(1.4 \%$ micronized $\mathrm{NaCl})$ - were evaluated with respect to sodium chloride content and by consumers using a nine-point hedonic scale for overall acceptability and CATA (check-all-that-apply) using 24 sensory descriptors. Trained panelists characterized the products using the flash profiling technique. Reductions in the salt content by up to $30 \%$ did not affect the overall acceptability of the samples by the consumers. However, the consumers characterized the formulations with lower salt content as "less salty and less seasoned" in comparison to the contents in the control. Products containing $1.7 \% \mathrm{NaCl}$ were considered very similar to the control. The results obtained indicate that it is possible to reduce $\mathrm{NaCl}$ content by $30 \%$ without affecting consumer acceptance of the product. The use of micronized salt did not affect the sensory characteristics when compared with those of formulations containing the same level of sodium chloride indicating that micronized salt does not influence perception of salt.
\end{abstract}

Keywords: check-all-that-apply (CATA); flash profiling; salt substitution; acceptability.

\section{Introduction}

Sodium consumption, linked primarily to sodium chloride content in foods, has been criticized for impacting human health over the past decades and has been correlated with the increasing incidence of hypertension. Meat products are considered to be one of the main contributors to this high sodium consumption. According to Katz \& Williams (2010), approximately $80 \%$ of the average consumer's sodium intake comes from processed meat products.

Reducing sodium in meat products is challenging. This compound is the most common ingredient used in processing and has many functions in addition to flavoring (Toldra \& Reig, 2011). Sodium chloride is responsible for extracting myofibrillar proteins and for increasing the ionic strength in the meat matrix improving various functional properties, including emulsifying capacity, gel formation, water binding, and fat binding (Horita et al., 2011).

Many studies in the literature have investigated the reduction of sodium in meat products (Guàrdia et al., 2008; Jimènez-Colmenero et al., 2010) and the substitution of sodium chloride for other salts, such as potassium chloride. There are fewer reports on how the reduction of sodium chloride alone impacts a product's sensory characteristics and its acceptance by consumers (Lucas et al., 2011). Some recent studies have indicated that a simple reduction in the size of the sodium chloride particles may provide a way of reducing overall sodium content in industrial formulations. Smaller sodium chloride particles can promote a higher perceived degree of saltiness because they dissolve more rapidly in the mouth. Kilcast \& Angus (2007) evaluated the effects of different sizes and varieties of sodium crystals in potato chips on trained panelists' perception using time-intensity methodology and observed that smaller crystals led to a faster, but less intense, perception of saltiness in comparison to that of larger crystals. However, no similar studies have been reported evaluating the substitution of sodium chloride for micronized salts.

Sensory techniques, such as CATA (check-all-that-apply) and flash profiling, are relatively new methods for conducting consumer studies and have been used to study jams (Dairou \& Sieffermann, 2002), powdered juices, (Ares et al., 2010b), iced teas (Veinand et al., 2011), and milk desserts (Ares et al., 2010a). Flash profile is a rapid sensory profiling technique designed to meet industrial needs by combining free-choice profiling with ranking. CATA has been introduced in consumer studies to determine which sensory attributes consumers perceive in a product. Given that both techniques are quite new, there are currently no reports available on their use in meat products.

The present study aims to identify the impact of salt reduction and its substitution for micronized salt on the sodium chloride content and sensory characteristics of turkey ham and to evaluate consumer acceptance for these modifications.

${ }^{1}$ Department of Food Technology, Faculty of Food Engineering, State University of Campinas - UNICAMP, Campinas, SP, Brazil, e-mail: materesagalvao@uol.com.br

2 BRF S.A., São Paulo, SP, Brazil

3 University of São Judas Tadeu, São Paulo, SP, Brazil

${ }^{*}$ Corresponding author 


\section{Materials and methods}

\subsection{Sample Preparation}

Five turkey ham formulations were prepared using different levels of sodium content, as shown in Table 1.

The micronized salt was obtained from Romani company (5\% retention on a mesh 20 sieve, Brazil). Ninety percent of the skinless turkey breast meat was ground through a $35 \mathrm{~mm}$ disc, and $10 \%$ was thawed and ground through a $10 \mathrm{~mm}$ disc. The other ingredients, with the exception of the cassava starch and the isolated soy protein, were added to $60 \%$ of the water to produce the brine. The meat and the brine mixture were homogenized for 20 min under vacuum, after which the remaining ingredients were added and mixed for an additional $10 \mathrm{~min}$. Approximately $0.8 \mathrm{~kg}$ of the product was stuffed into tubular casings (3.5' ' diameter) and cooked using a steam oven until it reached an internal temperature of $74^{\circ} \mathrm{C}$. After cooling in an ice bath, the products were stored at $4{ }^{\circ} \mathrm{C}$ for two weeks before the beginning the analysis.

\subsection{Salt and sodium content analysis}

The salt and sodium content was determined using the AOAC Official Method (Association of Official Analytical Chemists, 2007).

\subsection{Sensory evaluation}

The sensory protocol was previously approved by the Ethics in Research Committee of the University of Campinas, SP, Brazil under the number 1128/2011. All of the products were submitted to an acceptance test (overall acceptability) according to the method of Stone \& Sidel (2004) using 77 consumers of sliced-meat products as test subjects and a 9-point hedonic scale ( 1 =extremely disliked; $5=$ neither liked nor disliked; $9=$ extremely liked). The participants were offered water and a cracker between samples. After evaluating each product, the consumers were asked to select the words that expressed their opinion about the product they had tasted from a list of 24 sensory descriptors, following the protocol proposed by Ares et al. (2010a). The terms in the list were collected from previous studies in which consumers were asked to express their opinions about the same type of product using their own words. These terms, classified as descriptors of appearance, flavor, or texture, are presented in Table 2 .

Flash profiling was performed by six panelists trained in profiling other food categories, according to the procedures recommended by Dairou \& Siefferman (2002). A total of five sessions were conducted. The first and second were individual sessions and were intended to generate the list of individual attributes. The remaining sessions were used as opportunities

Table 1. Turkey ham formulations containing different amounts of refined or micronized salt (\%w/w).

\begin{tabular}{|c|c|c|c|c|c|}
\hline Ingredients & F1 & F2 & F3 & $\mathrm{F} 4$ & F5 \\
\hline Turkey breast & 70.0 & 70.0 & 70.0 & 70.0 & 70.0 \\
\hline Water & 23.6 & 23.8 & 24.2 & 23.8 & 24.2 \\
\hline Refined salt & 2.0 & 1.7 & 1.4 & 0 & 0 \\
\hline Micronized salt & 0 & 0 & 0 & 1.7 & 1.4 \\
\hline Cassava starch & 2.0 & 2.0 & 2.0 & 2.0 & 2.0 \\
\hline Isolated soy protein & 1.0 & 1.0 & 1.0 & 1.0 & 1.0 \\
\hline Sugar & 0.5 & 0.5 & 0.5 & 0.5 & 0.5 \\
\hline Seasonings & 0.01 & 0.01 & 0.01 & 0.01 & 0.01 \\
\hline Phosphate & 0.35 & 0.35 & 0.35 & 0.35 & 0.35 \\
\hline Carrageenan & 0.3 & 0.30 & 0.30 & 0.30 & 0.30 \\
\hline Monosodium glutamate & 0.20 & 0.20 & 0.20 & 0.20 & 0.20 \\
\hline Sodium erythorbate & 0.05 & 0.05 & 0.05 & 0.05 & 0.05 \\
\hline Sodium nitrite & 0.02 & 0.02 & 0.02 & 0.02 & 0.02 \\
\hline Cochineal carmine dye & 0.01 & 0.01 & 0.01 & 0.01 & 0.01 \\
\hline
\end{tabular}

Table 2. List of terms used for CATA survey.

\begin{tabular}{|c|c|c|}
\hline Appearance & Flavor & Texture \\
\hline $\begin{array}{l}\text { - Healthy appearance } \\
\text { - Ugly appearance } \\
\text { - Beautiful appearance } \\
\text { - Clear color } \\
\text { - Dark color }\end{array}$ & $\begin{array}{l}\text { - Salt in the right amount } \\
\text { - Bland taste } \\
\text { - Flavor } \\
\text { - Seasonings in the right amount } \\
\text { - Turkey meat taste in the right amount } \\
\text { - Strong turkey meatt flavor } \\
\text { - Strong overall flavor } \\
\text { - Salty } \\
\text { - Strong seasoning } \\
\text { - Weak turkey meatt flavor } \\
\text { - Weak overall flavor } \\
\text { - Without salt } \\
\text { - Without seasonings } \\
\text { - Bad flavor }\end{array}$ & $\begin{array}{l}\text { - Tenderness } \\
\text { - Juiciness } \\
\text { - Easy mastication } \\
\text { - Dry } \\
\text { - Hard }\end{array}$ \\
\hline
\end{tabular}


to rank the products in triplicate. The last three sessions were conducted at different times, and each lasted less than one hour.

\subsection{Statistical analysis}

The proximate composition data were statistically analyzed using the Tukey test at a significance level of 5\%. The acceptance data were subjected to analysis of variance (ANOVA) at a significance level of 5\%, and the data from CATA questions were analyzed using frequency of mentions. To evaluate whether the consumers perceived significant differences among the products, a Chi-Square test for $\mathrm{k}$ proportions was conducted using the $X \mathrm{LSTAT}^{\oplus} 2012 \mathrm{v} .05$ software. The sensory profile data from the flash profiling were analyzed by Generalized Procrustes Analysis (GPA) using the XLSTAT 2012 v.05 software.

\section{Results and discussion}

Data on sodium chloride (salt) content are presented in Table 3 .

The differences in the sodium content added and the sodium content analyzed were perceived as more acute in the formulations with micronized salts (F4 and F5). As a result, the effective reductions in the sodium content in samples F2, F3, $\mathrm{F} 4$, and $\mathrm{F} 5$ in comparison to the content of the control were $19 \%, 34 \%, 23 \%$, and $42 \%$, respectively. These significant sodium content decrease was expected. However, there were significant differences $(\mathrm{p}<0.05)$ between the formulations with the same sodium content added (e.g., F2 and F4 or F3 and F5), likely due to differences in the moisture content (i.e., hygroscopicity) between the two salts.

The results of the acceptability test are shown in Table 4.

No significant differences were detected among the products with respect to overall acceptability; the consumers moderately liked all of the formulations. Figure 1 illustrates the acceptance, rejection, and indifference levels for the five products studied revealing no relevant differences among the products for these levels. All products had $>90 \%$ acceptance.

The results from CATA are presented in Table 5. Of the 24 sensory descriptors given to the consumers to characterize the formulations, only three were found to differ significantly among the formulations: without salt, salty, and without seasoning.
The number of times the descriptor "without salt" was selected for the formulations with $1.4 \% \mathrm{NaCl}$ was statistically greater compared to that of the control. The descriptor "salty" was selected less frequently for the formulations containing $1.4 \%$ refined or micronized $\mathrm{NaCl}$ than the control. Both formulations with $1.4 \%$ salt and that with $1.7 \%$ micronized salt were statistically more frequently described as "without seasoning" than the control.

The list of terms generated by each subject in the flash profiling test is presented in Table 6.

The number of sensory descriptors generated by each subject varied from two to nine. Altogether, the panelists selected 19 terms related to flavor and texture. The only common sensory descriptor found was "salty taste".

The first two principal components accounted for $77.39 \%$ of the total variability among the samples. The product positions and their sensory characterizations are presented in Figures 2 and 3 , respectively.

The GPA analysis led to the formation of three groups. The first contained the control sample, F1 (2\% salt), and F2 (1.7\% salt). F3 (1.4\% salt) and F4 (1.7\% micronized salt) generated a second group, whereas group 3 consisted of only F5 (1.4\% micronized salt). Based on this analysis, the sample with $1.7 \%$ salt may be considered the most similar to the control. Analysis of the sensory descriptors indicates that both F1 and F2 are characterized by their salty taste and seasonings, whereas $\mathrm{F} 3$ and

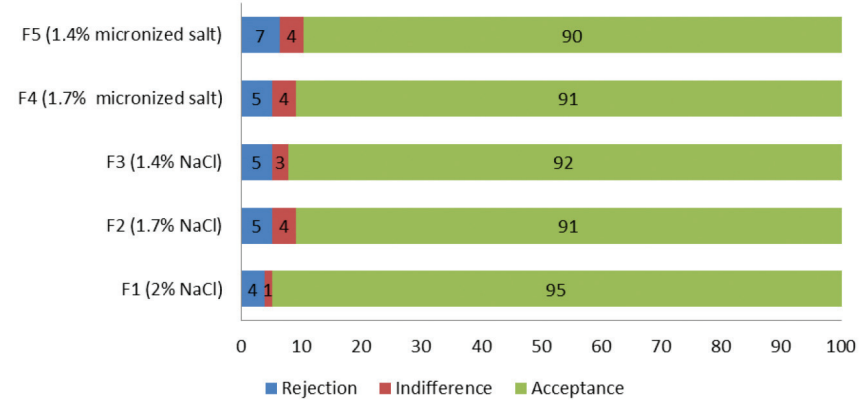

Figure 1. Acceptance, rejection, and indifference levels for each formulation.

Table 3. Sodium chloride content and sodium content of the formulations.

\begin{tabular}{lccccc}
\hline & F1 & F2 & F3 & F4 & $1.51^{\mathrm{d}}$ \\
\hline Sodium Chloride (\%) & $1.95^{\mathrm{a}}$ & $1.58^{\mathrm{b}}$ & $1.28^{\mathrm{c}}$ & $7.14^{\mathrm{e}}$ & $879^{\mathrm{b}}$ \\
Sodium (mg/100 g) & $1048^{\mathrm{a}}$ & $915^{\mathrm{b}}$ & $740^{\mathrm{c}}$ & $761^{\mathrm{c}}$ \\
\hline a, b, c, d, e- Measurements in the same row with matching letters did not differ significantly at p $<0,05$ (Tukey's test). F1-2.0\% NaCl; F2-1.7\% NaCl; F3-1.4\% NaCl; F4-1.7\% micronized \\
NaCl; F5-1.4\% micronized NaCl.
\end{tabular}

Table 4. Degree of overall acceptability and standard deviation of the formulations.

\begin{tabular}{cccccc}
\hline & F1 & F2 & F3 & F4 & F5 \\
\hline Overall acceptability & $7.34^{\mathrm{a}}$ & $7.23^{\mathrm{a}}$ & $7.18^{\mathrm{a}}$ & $7.32^{\mathrm{a}}$ & $7.04^{\mathrm{a}}$ \\
Standard deviation & 1.26 & 1.56 & 1.44 & 1.42 & 1.46 \\
\hline
\end{tabular}

a - Measurements in the same row with matching letters did not differ significantly at p < 0.05 (Tukey's test). F1-2\% NaCl; F2-1.7\% NaCl; F3-1.4\% NaCl; F4-1.7\% micronized NaCl; F5-1.4\% micronized $\mathrm{NaCl}$. 
Objects (axis F1 and F2: 77.39\%)

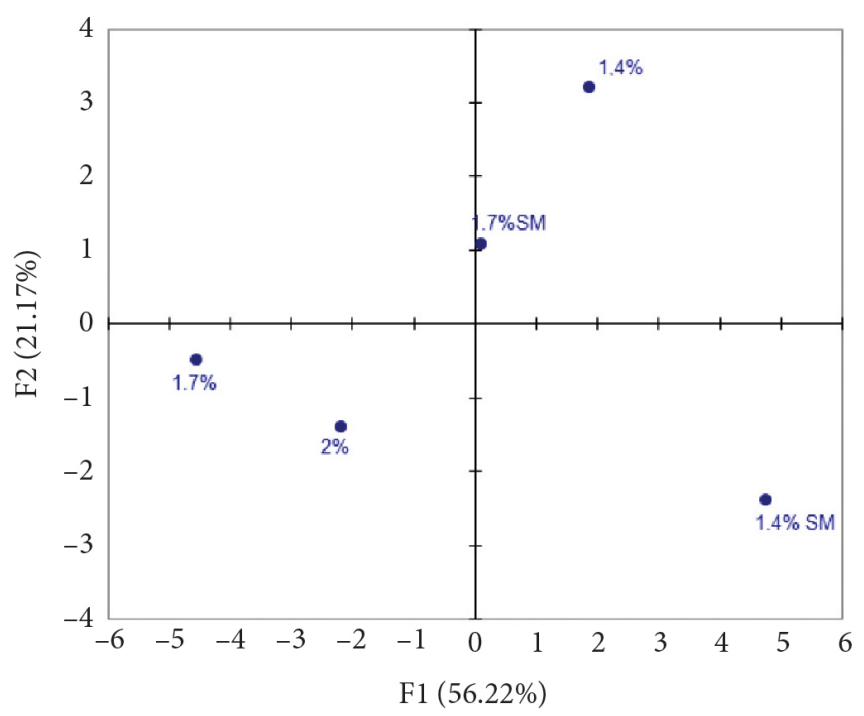

Figure 2. Mean products plotted on the first two principal axes. F1$2 \% \mathrm{NaCl}$; F2-1.7\% NaCl; F3-1.4\% NaCl; F4-1.7\% micronized NaCl; F5-1.4\% micronized $\mathrm{NaCl}$.
F4, positioned on the opposite quadrant, exhibited a different flavor and texture profile. These products were characterized according to their blandness or meat taste and to the presence of an aftertaste. F5 was characterized primarily according to texture, with negative descriptors such as "dry" and "brittle."

\section{Conclusion}

The substitution of refined salt for the same weight of micronized salt, (same amount)-reduced the salt content slightly but did not promote significant changes in the sodium content.

With respect to the sensory analysis, salt reductions by up to $30 \%$ did not influence the consumer acceptance of products despite the fact that the consumers charcterized the formulations tested as less salty and less seasoned than the control. The use of micronized salt to substitute table salt did not increase saltiness perception. Sensory profiling revealed that salt reductions resulted in products that were perceived as less salty and less seasoned. High levels of salt reduction in products containing micronized salt also affected texture characteristics. Products containing low levels of salt were considered to be dry and brittle. Color was not affected by salt reduction.

Table 5. Total counts of CATA attributes used to characterize the formulations containing either reduced sodium or micronized salt.

\begin{tabular}{|c|c|c|c|c|c|}
\hline Descriptors & $\mathrm{F} 1$ & $\mathrm{~F} 2$ & F3 & $\mathrm{F} 4$ & F5 \\
\hline Healthy appearance & $49^{\mathrm{a}}$ & $47^{\mathrm{a}}$ & $46^{\mathrm{a}}$ & $52^{\mathrm{a}}$ & $41^{\mathrm{a}}$ \\
\hline Tenderness & $45^{\mathrm{a}}$ & $41^{\mathrm{a}}$ & $42^{\mathrm{a}}$ & $43^{\mathrm{a}}$ & $41^{\mathrm{a}}$ \\
\hline Beautiful appearance & $42^{\mathrm{a}}$ & $40^{\mathrm{a}}$ & $42^{\mathrm{a}}$ & $49^{\mathrm{a}}$ & $36^{\mathrm{a}}$ \\
\hline Flavor & $39^{\mathrm{a}}$ & $37^{\mathrm{a}}$ & $24^{\mathrm{a}}$ & $37^{\mathrm{a}}$ & $29^{\mathrm{a}}$ \\
\hline Bland taste & $38^{\mathrm{a}}$ & $44^{\mathrm{a}}$ & $40^{\mathrm{a}}$ & $42^{\mathrm{a}}$ & $40^{\mathrm{a}}$ \\
\hline Seasonings in the right amount & $34^{\mathrm{a}}$ & $30^{\mathrm{a}}$ & $22^{\mathrm{a}}$ & $28^{\mathrm{a}}$ & $23^{\mathrm{a}}$ \\
\hline Clear color & $32^{\mathrm{a}}$ & $37^{\mathrm{a}}$ & $36^{\mathrm{a}}$ & $41^{\mathrm{a}}$ & $42^{\mathrm{a}}$ \\
\hline Juiciness & $32^{\mathrm{a}}$ & $30^{\mathrm{a}}$ & $29^{a}$ & $32^{\mathrm{a}}$ & $20^{\mathrm{a}}$ \\
\hline Salt in the right amount & $29^{\mathrm{a}}$ & $24^{\mathrm{a}}$ & $19^{\mathrm{a}}$ & $27^{\mathrm{a}}$ & $20^{\mathrm{a}}$ \\
\hline Turkey meat taste in the right amount & $21^{\mathrm{a}}$ & $20^{\mathrm{a}}$ & $19^{\mathrm{a}}$ & $25^{\mathrm{a}}$ & $20^{\mathrm{a}}$ \\
\hline Easy mastication & $14^{\mathrm{a}}$ & $20^{\mathrm{a}}$ & $23^{\mathrm{a}}$ & $21^{\mathrm{a}}$ & $21^{\mathrm{a}}$ \\
\hline Strong turkey meat flavor & $12^{\mathrm{a}}$ & $8^{a}$ & $9^{a}$ & $7^{\mathrm{a}}$ & $9^{a}$ \\
\hline Strong overall flavor & $12^{\mathrm{a}}$ & $4^{\mathrm{a}}$ & $4^{\mathrm{a}}$ & $3^{\mathrm{a}}$ & $3^{\mathrm{a}}$ \\
\hline Salty & $12^{\mathrm{a}}$ & $4^{\mathrm{ab}}$ & $1^{\mathrm{b}}$ & $2^{\mathrm{ab}}$ & $1^{\mathrm{b}}$ \\
\hline Strong seasoning & $9^{a}$ & $6^{\mathrm{a}}$ & $6^{\mathrm{a}}$ & $2^{\mathrm{a}}$ & $2^{a}$ \\
\hline Weak turkey meat flavor & $5^{a}$ & $13^{\mathrm{a}}$ & $17^{\mathrm{a}}$ & $14^{\mathrm{a}}$ & $16^{\mathrm{a}}$ \\
\hline Weak overall flavor & $4^{\mathrm{a}}$ & $8^{a}$ & $13^{\mathrm{a}}$ & $13^{\mathrm{a}}$ & $18^{\mathrm{a}}$ \\
\hline Dry & $4^{\mathrm{a}}$ & $4^{\mathrm{a}}$ & $8^{\mathrm{a}}$ & $10^{\mathrm{a}}$ & $14^{\mathrm{a}}$ \\
\hline Ugly appearance & $2^{\mathrm{a}}$ & $3^{a}$ & $7^{a}$ & $3^{a}$ & $7^{\mathrm{a}}$ \\
\hline Hard & $2^{\mathrm{a}}$ & $2^{\mathrm{a}}$ & $2^{\mathrm{a}}$ & $4^{\mathrm{a}}$ & $2^{\mathrm{a}}$ \\
\hline Without salt & $1^{\mathrm{b}}$ & $9^{\mathrm{ab}}$ & $14^{\mathrm{a}}$ & $12^{\mathrm{ab}}$ & $20^{\mathrm{a}}$ \\
\hline Without seasoning & $1^{\mathrm{b}}$ & $7^{\mathrm{ab}}$ & $15^{\mathrm{a}}$ & $9^{a}$ & $17^{\mathrm{a}}$ \\
\hline Bad flavor & $1^{\mathrm{a}}$ & $3^{a}$ & $5^{a}$ & $2^{\mathrm{a}}$ & $4^{\mathrm{a}}$ \\
\hline Dark color & $1^{\mathrm{a}}$ & $1^{\mathrm{a}}$ & $0^{\mathrm{a}}$ & $2^{\mathrm{a}}$ & $0^{\mathrm{a}}$ \\
\hline
\end{tabular}

a, b, - Measurements in the same row with matching letters did not differ significantly at p < 0.05 (Tukey's test). F1-2\% NaCl; F2-1.7\% NaCl; F3-1.4\% NaCl; F4-1.7\% micronized NaCl; F5-1.4\% micronized $\mathrm{NaCl}$. 
Table 6. Descriptors generated by each subject in the flash profiling test.

\begin{tabular}{|c|c|c|c|c|c|}
\hline Subject 1 & Subject 2 & Subject 3 & Subject 4 & Subject 5 & Subject 6 \\
\hline Salty taste & Salty taste & Salty taste & Salty taste & Salty taste & Salty taste \\
\hline Meat flavor & Meat flavor & Smoked flavor & Flavor intensity & Seasoning flavor & Bitter taste \\
\hline Strange taste & Seasoning flavor & Dry texture & Juiciness & Sour taste & \\
\hline Aftertaste & Turkey flavor & Brittle texture & Turkey breast flavor & Tenderness & \\
\hline Seasoning flavor & Bland flavor & & & Rough texture & \\
\hline Juiciness & Brittle texture & & & Granular texture & \\
\hline Meat bite & Dry texture & & & & \\
\hline Astringency & Tenderness & & & & \\
\hline Tenderness & & & & & \\
\hline
\end{tabular}

Dimensions (axis F1 and F2: 77.39\%)

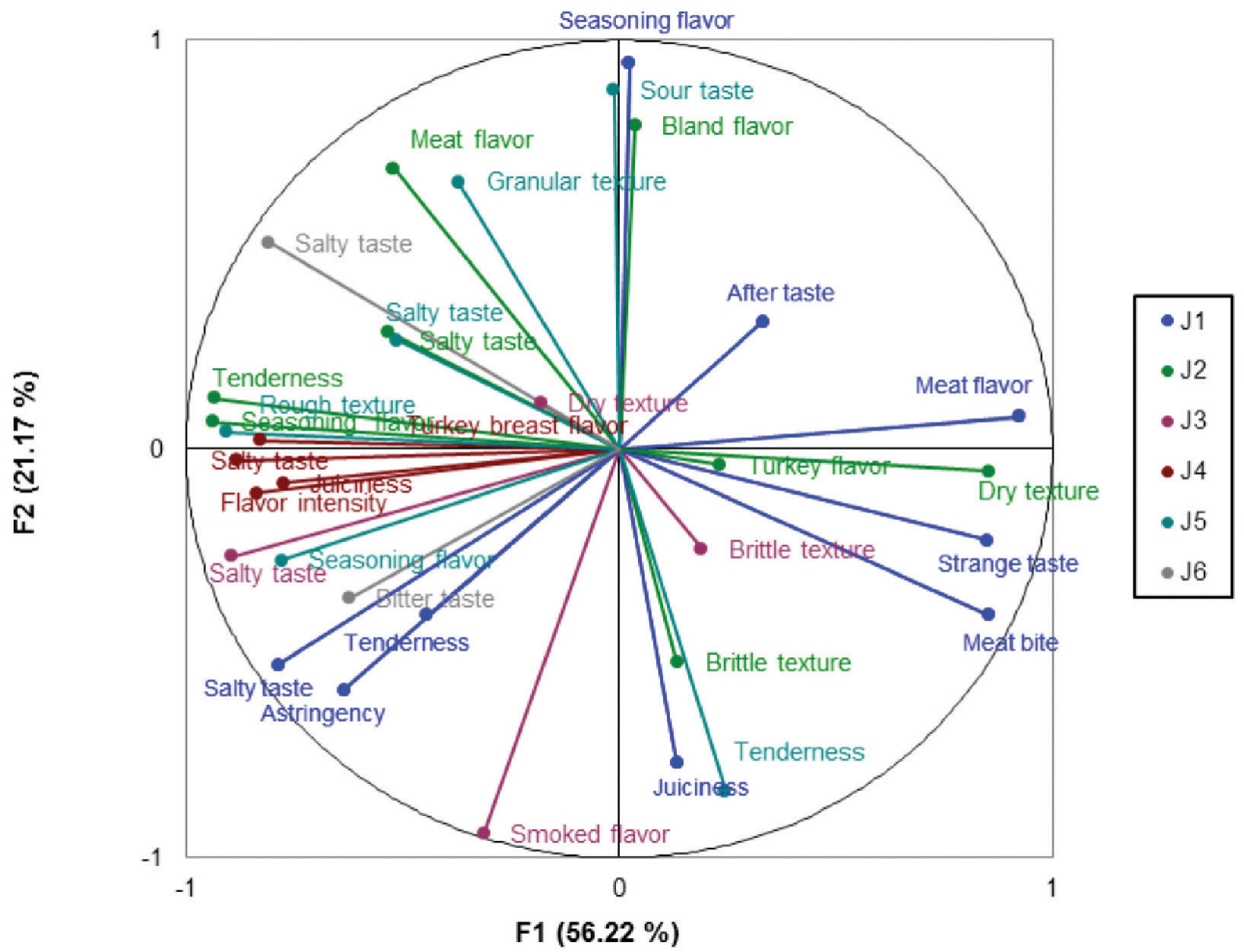

Figure 3. Terms plotted for each panelist from flash profiling using GPA analysis.

\section{References}

Ares, G., Barreiro, C., Deliza, R., Gimènez, A., \& Gámbaro, A. (2010a). Application of check-all-that-apply questions to the development of chocolate milk desserts. Journal of Sensory Studies, 25(1), 67-86.

Ares, G., Deliza, R., Barreiro, C., Gimènez, A., \& Gambarro, A. (2010b). Comparison of two sensory profiling techniques based on consumer perception. Food Quality and Preference, 21(4), 417-426. http:// dx.doi.org/10.1016/j.foodqual.2009.10.006
Association of Official Analytical Chemists. (2007). Official Methods of Analysis (18th ed.) Washington: AOAC.

Dairou, V., \& Sieffermann, J. M. (2002). Comparison of 14 jams characterized by conventional profile and a quick original method, the Flash profile. Journal of Food Science, 67(2), 826-834. http:// dx.doi.org/10.1111/j.1365-2621.2002.tb10685.x

Guàrdia, M. D., Guerrero, L., Gelabert, J., Gou, P., \& Arnau, J. (2008). Sensory characterization and consumer acceptability of small calibre 
fermented sausage with $50 \%$ substitution of $\mathrm{NaCl}$ by mixtures of $\mathrm{KCl}$ and potassium lactate. Meat Science, 8(4), 1225-1230. http:// dx.doi.org/10.1016/j.meatsci.2008.05.031

Horita, C. N., Morgano, M. A., Celeghini, R. M. S., \& Pollonio, M. A. R. (2011). Physico-chemical and sensory properties of reducedfat mortadella prepared with blends of calcium, magnesium and potassium chloride as partial substitutes for sodium chloride. Meat Science, 89(4), 426-433. http://dx.doi.org/10.1016/j. meatsci.2011.05.010

Jimènez-Colmenero, F., Cofrades, F., Lópes-Lópes, I., Ruiz-Capillas, C., Pintado, T., \& Solas, M. T. (2010). Technological and sensory characteristics of reduced/low fat, low-salt frankfurters as affected by the addition of kinjac and seaweed. Meat Science, 84(3), 356-363. http://dx.doi.org/10.1016/j.meatsci.2009.09.002

Katz, B., \& Williams, L. A. (2010). Salt reduction: gains momentum. Food Technology, 64(5), 24-32.

Kilcast, D., \& Angus, F. (2007). Reducing salt in foods. Cambridge: Woodhead Publishing Limited. http://dx.doi. org/10.1533/9781845693046
Lucas, L., Riddell, L., Liem, G., Whitelock, S., \& Keast, R. (2011). The influence of sodium on liking and consumption of salty food. Journal of Food Science, 76(1), S72-S76. http://dx.doi.org/10.1111/j.17503841.2010.01939.x

Stone, H., \& Sidel, J. L. (2004). Affective Testing. In H. Stone \& J. L. Sidel (Eds.), Sensory evaluation practices (chapter 7, pp. 247-277). San Diego: Elsevier Academic Press. http://dx.doi.org/10.1016/ B978-012672690-9/50011-1

Toldra, F., \& Reig, M. (2011). Innovations for healthier processed meats. Trends in Food Science and Technology, 22(2011), 517-522. http:// dx.doi.org/10.1016/j.tifs.2011.08.007

Veinand, B., Godefroy, C., Adam, C., \& Delarue, J. (2011). Highlight of important product characteristics for consumers: comparison of three sensory descriptive methods performed by consumers. Food Quality and Preference, 22(5), 474-485. http://dx.doi.org/10.1016/j. foodqual.2011.02.011 